\title{
Net Income and CSR Disclosure as Predictors Shares Price and Return per Share
}

\author{
Wahyuni Rusliyana Sari ${ }^{\bowtie}$, Anita Roosmalina Matusin \\ Faculty of Economics and Business, Universitas Trisakti, Jakarta, Indonesia
}

\begin{tabular}{l} 
Info Article \\
\hline History Article: \\
Received 24 April 2019 \\
Approved 24 August 2019 \\
Published March 2019 \\
\hline Keywords: \\
Book Value per Share; Net Income; \\
CSR Environment; CSR Social; \\
CSR Report; CSR Total; Share \\
Prices; Return per Share. \\
\hline
\end{tabular}

\begin{abstract}
The purpose of this study was to determine the factors that influence shares price and return per share of 63 manufacturing companies period 2012-2016. The research method is multiple linear regression analysis, which done by the classical assumption test. The results of the research in the first model show that there is a positive influence between book value per share, net income, CSR social, and CSR report on shares price. While in the second model using the enter method shows delta net income and delta CSR total had a positive effect on return per shares, and delta CSR environment has a negative effect on return per share, while those using stepwise method delta CSR social and delta CSR net income had a positive impact on return per share. The contribution of this study is to provide information to stakeholders that CSR environment does not have an important role in shares prices, prioritizing the interests of shareholders, which means that the CSR environmental measurement instruments focus on disclosure, and ignore fundamental aspects, namely environmental liabilities. The implication is that the regulator, investor, and profession needs to more pay attention to CSR environmental.
\end{abstract}

\section{Net Income dan CSR Disclosure Sebagai Prediktor Shares Price dan Return per Share}

\begin{abstract}
Abstrak
Tujuan penelitian ini adalah untuk mengetahui faktor-faktor yang memengaruhi harga saham dan return per share pada 63 perusahaan manufaktur go public periode 2012-2016. Metode penelitian ini adalah analisis regresi linier berganda dengan menggunakan dua model yang sudah lolos uji asumsi klasik. Hasil dari penelitian pada model pertama menunjukkan terdapat pengaruh positif antara book value per share, net income, CSR sosial dan laporan CSR terhadap harga saham, sedangkan pada model kedua yang menggunakan enter method menunjukkan terdapat pengaruh positif delta net income dan delta CSR total terhadap return per shares, delta CSR environment berpengaruh negatif terhadap return per shares, sementara yang menggunakan stepwise method delta CSR sosial dan delta CSR net income berpengaruh positif terhadap return per share. Kontribusi dari penelitian ini adalah untuk memberikan informasi kepada para pemangku kepentingan bahwa CSR lingkungan tidak memiliki peran penting dalam menentukan harga saham, mengutamakan kepentingan pemegang saham, yang berarti bahwa instrumen pengukuran CSR lingkungan berfokus pada pengungkapan, dan mengabaikan aspek fundamental, yaitu kewajiban lingkungan. Implikasi dari penelitian ini adalah pihak regulator, investor, dan profesi perlu lebih memerhatikan peran CSR lingkungan.
\end{abstract}

JEL Classification: G1, G12

How to Cite: Sari, W. R., \& Matusin, A. R. (2019). Net Income and CSR Disclosure as Predictors Shares Price and Return per Share. Jurnal Dinamika Manajemen, 10(1), 81-91. 


\section{INTRODUCTION}

The main objective of the company is not only to increase profits but to maximize shareholder wealth. Currently, one of the indicators seen by investors is corporate social responsibility (CSR), which is also an interesting thing for both researchers and academics (Verbeeten et al., 2016). The problem of social and environmental impacts warmly discussed among companies because of the imbalance between the rapid growth of the industry and the environmental impacts that arise will ultimately harm the business itself (Garcia-Sanchez et al., 2014). Issues about pollution, waste, declining resources, product quality and security, rights and status of workers, are the focus of concern that continues to improved in this context companies are required to contribute more to thinking about society than shareholders and creditors (Reverte, 2009).

With global climate conditions, the company's environmental management has undergone drastic changes that is characterized by business organizations that continue to improve social and environmental concerns (Kuo et al., 2013). The increasing number of CSR reports it implemented in each company is very useful and helpful, there is a view academic evidence regarding the relevance of specific CSR disclosures (Clarkson et al., 2013).

It turned out that this attracted the attention of academics and practitioners as revealed that CSR report was expensive, even though the number of companies in the world that presented CSR reports since the 1990s such as the environment, protection of human rights, improvement of employee welfare, and contribution to the community and society (Dhaliwal et al., 2014). In addition, the CSR report was also reported to improve financial performance, image, strong reputation, and corporate identity (Arendt \& Brettel, 2010), reducing financial risk reflected in the implications of implementing significant CSR on the economy, social, and environment (Mishra \& Modi, 2013), provide easy access to finance where the large amount of fundamental attention, namely CSR, leads to value creation (Cheng et al., 2014).

CSR and the company's financial performance has been sufficiently explored by strategy, management, organizational literature, and CSR report also decreases the cost of equity (Reverte, 2012). CSR disclosure also useful for analysts to assess the company's financial performance in a stakeholder-oriented country rather than a country that oriented to shareholders, it is a positive relationship between CSR disclosure and estimated accuracy predicted analysts are more prominent in stakeholder-oriented countries (Dhaliwal et al., 2012). The cost-benefit analysis of CSR has long debated, the extant literature largely recognizes the role of value-driven CSR and presents substantial evidence that CSR activities can play an important role in increasing corporate value and benefits as a result of superior social and environmental performance (Malik, 2015).

Stakeholders demand more information transparency from companies, and this encourages companies to publish CSR information (Kim et al., 2012). Corporate transparency is important in a healthy and effective CSR, now investors do not only see profits but CSR disclosure, and the higher the level of CSR disclosure the better the company's image (Chakroun et al., 2016).

It found that the weight of the argument that the company did not disclose choosing not to do since it was due to immateriality, the company revealed seeing strategic value in the choice to disclose (Cho et al., 2012). As an alternative, the sociopolitical theory includes legitimacy theory and stakeholders who predict a negative relationship between CSR disclosure and share prices that has been proven from the results of several previous studies conducted by (Monteiro \& Aibar-Guzmán, 2010; Cho et al., 2012; Kuo et al., 2013).

The share price is defined as the closing price of shares at the end of the year in December, which directly taken from the company's financial statements (Al-Troudi \& Milhem, 2013). There are several ways to calculate shares prices, namely with the average of the maximum 
and minimum share prices and the closing price (Almumani, 2014). In line with previous research in this study using the closing price as a measure of shares prices (Verbeeten et al., 2016).

The level of profit is used as a measure of investors before investing and even becomes the most important thing when a company will determine a decision because it is related to cash flow which includes expenditures for dividend payments or as earnings returns (Lys et al., 2015). Profits obtained by the company sometimes above or below the average profit; these conditions are called daily abnormal returns and accumulative abnormal returns (Xu et al., 2012). In line with previous research, return per share is used as a comparison of the dependent variable with share price (Verbeeten et al., 2016).

CSR activities can enhance the company's image in the community perspective and increase the attractiveness of investors (Cheng \& Christiawan, 2011). CSR refers to the company's voluntary contributions to sustainable development that goes beyond legal requirements referring to the company's contribution to sustainable development (Arendt \& Brettel, 2010; Kuo et al., 2013). In general, companies report CSR activities and reports to stakeholders (Dhaliwal et al., 2011; Reverte, 2009, 2016). Some nongovernmental organizations develop models or thought frameworks for CSR reporting, including Internationally Standards Organizations (ISO 14001), the World Resources Institute and GRI. Based on the GRI guidelines, content analysis is used to build the amount of CSR disclosure from information presented by company reports (Verbeeten et al., 2016).

CSR disclosure is defined as information disclosed by the company regarding environmental impacts and its relationships with stakeholders through relevant communication channels (Gamerschlag et al., 2011). Business organizations are increasingly considered responsible for their concern for social and environmental impacts (Mishra \& Modi, 2013). CSR social disclosure provides an indication of the company's workforce that can drive the company's financial performance in the future; this can encourage an increase in a company's shares price which shows that the company's value is good (Flammer, 2015). There is a positive influence between CSR disclosure on shares prices if the level of disclosure of CSR issued by the company is high, then the value of the company will be better (Klerk et al., 2015).

Companies that publish CSR reports are more likely to provide useful information in stages for investors to evaluate the long-term sustainability of a company (Verbeeten et al., 2016). It is found that CSR reports had a positive effect on market value (Berthelot et al., 2012; Verbeeten et al., 2016).

According to Verbeeten et al. (2016) in Germany of 18 industries in 130 companies registered at Deutsche Boerse 2005-2008, the results of this study have a positive influence between CSR social with shares prices and CSR environmental having a negative but not significant correlation. While research Clarkson et al. (2013) find a positive influence between CSR environmental on company value. Bird, Hall, Momentè \& Reggiani (2007) found a significant negative effect between CSR environmental on firm value.

The contribution of this study is to provide information to stakeholders that CSR environment does not have an important role in shares prices, prioritizing the interests of shareholders, which means that the CSR environmental measurement instruments focus on disclosure, and ignore fundamental aspects, namely environmental liabilities.

\section{Hypothesis Development}

Book value defined as each book value sheet obtained from the division between ordinary equity shares and the number of ordinary shares outstanding (Almumani, 2014). Book value as one of the shares price measurement indicators that describe the investment per share held by shareholders, the higher the book value indicates the higher the financial performance of the company (Carnevale et al., 2012). Overall, the high book value of a company will increase shares prices (Reverte, 2016). Relevant to 
previous research that one of the factors that affect share price and return per share (Verbeeten et al., 2016).

Book value is one method for comparing company values. In general, the high book value per share will increase the shares price. Some previous studies stated that there is a positive influence between book value and share price (Sharma, 2011; Srinivasan, 2012; Malhotra \& Tandon, 2013; Almumani, 2014; Reverte, 2016; Verbeeten et al., 2016).

$\mathrm{H} 1$ : Book value per share has a positive effect on shares price.

Huge net income will generally increase shares prices regardless of normal or abnormal return, the greater the company's profit will be positively correlated with the intention of investors to invest in the company (Almeida et al., 2016). Net income is one of the indicators used to measure shares prices, although in general the research uses measurements of profitability ratios such as earnings per share, return on assets, return on equity, net profit margin, and operating profit margin, how a company will have a share value high if the net income is low (Malhotra \& Tandon, 2013). The existence of a positive influence shows that higher net income can increase the company's share price (Verbeeten et al., 2016).

Net income is an important indicator in measuring financial performance. Therefore high net income will increase share price. In line with the results of previous studies that net income has a positive effect on shares prices (Malhotra \& Tandon, 2013; Almeida et al., 2016; Verbeeten et al., 2016).

$\mathrm{H} 2$ : Net income has a positive effect on shares price.

Negative influence between environmental disclosures on company value (Bird et al., 2007). There is a negative influence between CSR environment on share price, meaning that if the level of environmental disclosure is high, then the value of the company will decrease (Verbeeten et al., 2016).
H3: CSR environment has a negative effect on shares price.

Positive influence between social disclosures on firm value (Bird et al., 2007). CSR social has a positive effect on share price, which means that if social CSR rises it will increase shares prices (Verbeeten et al., 2016).

H4: CSR social has a positive effect on shares price.

When a company presents a CSR report, it will enhance the company's image because it attracts investors to invest, in line with the results of previous studies that there is a positive influence between CSR report on share price (Berthelot et al., 2012; Carnevale et al., 2012; Verbeeten et al., 2016).

H5: CSR report has a positive effect on the share price.

Net income is one of the measurements that company is good performance. Indonesian companies showed that net income always has a positive impact on return per share in this case. Therefore high net income will increase return per share (Malhotra \& Tandon, 2013; Almeida et al., 2016; Verbeeten et al., 2016).

H6: Net income has a positive effect on return per share.

Delta net income is a linear relationship with net income; the higher net income will be increasing the delta net income. The higher delta net income than the return per share will be increase (Malhotra \& Tandon, 2013; Almeida et al., 2016; Verbeeten et al., 2016).

H7: Delta net income has a positive effect on return per share.

Delta CSR environment is depended on the CSR environment; it means the value is linear. In this case there is the negative impact between delta CSR environment on return per share (Bird et al., 2007; Verbeeten et al., 2016). H8: Delta CSR environment has a negative effect on return per share. 
Wahyuni Rusliyana Sari \& Anita Roosmalina Matusin/ Net Income and CSR Disclosure as Predictors Shares....

Delta CSR social have a linear positive relationship with CSR social. Bird et al. (2007) find a positive influence between delta CSR social on return per share. This result also supports Verbeeten et al. (2016).

H9: Delta CSR social has a positive effect on return per share.

CSR report is one of an important thing in the companies, investors affected by the CSR report. Delta total CSR has a positive impact on return per share (Berthelot et al., 2012; Carnevale et al., 2012). Another study showed that the delta total CSR had a linear relationship with return per share (Verbeeten et al., 2016).

H10: Delta total CSR has a positive effect on return per share.

\section{METHOD}

The research design used in this study is hypothesis testing to analyze the effect of net income and CSR disclosure on shares price and return per share. Measurements for these variables can be seen in Table 1 .

The research sample was taken by purposive sampling method, which is a sampling method based on certain criteria and considerations (Sekaran \& Bougie, 2013). The criteria for determining the sample in this study are as follows: (1) Manufacturing companies listed on the Indonesia Stock Exchange during the period; (2) Manufacturing companies that provide financial statements in rupiah; (3) Manufacturing companies that provide CSR report in the annual report for the period; (4) Manufacturing companies that publish shares prices during the period; and (5) Manufacturing companies that have issued dividends during the period.

Secondary data used in this research were 63 companies period 2012-2016 in the manufacturing companies listed on the Indonesia Stock Exchange with the result that 315 observations. The study used multiple linear regression analysis which is done by classic assumption

Table 1. Variables and Measurements

\begin{tabular}{|c|c|c|}
\hline Variables & Proxy & Measurements \\
\hline \multicolumn{3}{|l|}{ Dependent Variable } \\
\hline Shares price & SP & Share price at the end of the fiscal year \\
\hline Return per share & RET & Return per share over the year ending at the end of the quarter \\
\hline \multicolumn{3}{|l|}{ Independent Variables } \\
\hline Book value per share & BVPS & Equity $/(\Sigma$ Common shares outstanding share $)$ \\
\hline \multirow[t]{2}{*}{ Net income } & NI & Sales revenue-COGS-Operating expenses-interest expenses-taxes \\
\hline & DNI & $\mathrm{NI}_{\mathrm{t}}-\mathrm{NI}_{\mathrm{t}-1}$ \\
\hline \multirow[t]{4}{*}{ CSR disclosures } & CSRENV & $\begin{array}{c}\text { ( } \text { keywords revealed regarding the environment }) /\left(\sum \text { maximum list }\right. \\
\text { of keywords related to the environment) }\end{array}$ \\
\hline & CSRSOC & $\begin{array}{c}\text { (Ekeywords revealed regarding the social) } /\left(\sum \text { maximum list of }\right. \\
\text { keywords related to the social) }\end{array}$ \\
\hline & DCSRENV & $\mathrm{CSRENV}_{\mathrm{t}}-\mathrm{CSRENV}_{\mathrm{t}-1}$ \\
\hline & DCSRSOC & $\mathrm{CSRSOC}_{t}-\mathrm{CSRSOC}_{\mathrm{t}-1}$ \\
\hline \multirow[t]{3}{*}{ CSR report } & CSRR & $\begin{array}{l}\text { Measure by dummy variables: } \\
\text { The value } 0 \text { (zero) if the company does not provide separate CSR } \\
\text { reports. The value } 1 \text { (one) if the company provide separate CSR } \\
\text { reports. }\end{array}$ \\
\hline & CSRTOT & $\begin{array}{l}\text { is the total quantity of CSR disclosures (i.e., the total number of } \\
\text { words on CSR topics based on the list in Table } 2 \text { in the annual } \\
\text { report and the CSR report) }\end{array}$ \\
\hline & DCSRTOT & $\mathrm{CSRTOT}_{t}-\mathrm{CSRTOT}_{\mathrm{t}-1}$ \\
\hline
\end{tabular}


test. Presented two multiple linear regression models, there are:

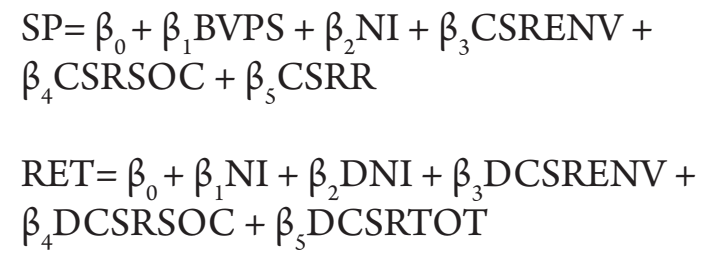

Where in:

$\begin{array}{ll}\text { SP } & =\text { Share prices } \\ \text { RET } & =\text { Return per share } \\ \beta_{0} & =\text { Constanta } \\ \beta_{1}-\beta_{\mathrm{n}} & =\text { Variable regression coefficient } \\ \text { BVPS } & =\text { Book value per share } \\ \text { NI } & =\text { Net income } \\ \text { DNI } & =\text { Delta net income } \\ \text { CSRENV } & =\text { CSR environment } \\ \text { DCSRENV } & =\text { Delta CSR environment } \\ \text { CSRSOC } & =\text { CSR social } \\ \text { DCSRSOC } & =\text { Delta CSR social } \\ \text { CSRR } & =\text { CSR report } \\ \text { DCSRTOT } & =\text { Delta CSR total }\end{array}$

\section{RESULT AND DISCUSSION}

In this section show descriptive statistics for two regression models. Table 3 showed that the shares price, book value per share, and net income as an indisputable portrait to see the real conditions of manufacturing companies in
Table 2. Keywords for the Content Analysis Derived from the GRI Framework

\begin{tabular}{|c|c|}
\hline Environmental & Social \\
\hline $\begin{array}{l}\text { Recycled } \\
\text { Energy } \\
\text { consumption Bio- } \\
\text { diversity } \\
\text { Emissions } \\
\text { Effluents } \\
\text { Waste } \\
\text { Spills } \\
\text { Environmental im- } \\
\text { pacts }\end{array}$ & $\begin{array}{l}\text { Employment } \\
\text { Employee turnover } \\
\text { Collective bargaining } \\
\text { Collective agreements } \\
\text { Occupational health } \\
\text { Occupational safety } \\
\text { Training } \\
\text { Diversity } \\
\text { Equal opportunities } \\
\text { Human rights } \\
\text { Discrimination } \\
\text { Freedom of association } \\
\text { Child labor } \\
\text { Forced labor } \\
\text { Compulsory labor } \\
\text { Community } \\
\text { Corruption } \\
\text { Public policy } \\
\text { Compliance } \\
\text { Fines } \\
\text { Sanctions } \\
\text { Product responsibility } \\
\text { Customer health } \\
\text { Customer safety }\end{array}$ \\
\hline
\end{tabular}

Indonesia, which are reflected in the standard deviation values greater than the mean and extreme range between minimum and maximum values. Table 4 showed that the return per share and delta net income is liner with the first mo-

Tabel 3. Descriptive Statistic Model 1

\begin{tabular}{lcrrrr}
\hline Variable & $\mathbf{N}$ & \multicolumn{1}{c}{ Minimum } & \multicolumn{1}{c}{ Maximum } & \multicolumn{1}{c}{ Mean } & \multicolumn{1}{c}{ Std. Deviation } \\
\hline SP & 162 & 50.00 & $7,550.00$ & 532.61 & $1,035.57$ \\
BVPS & 162 & -169.11 & $8,739.59$ & $1,098.44$ & $1,773.51$ \\
NI (in IDR mio) & 162 & $-474,046$ & $22,742,000$ & 608,328 & $3,030,681$ \\
CSRENV & 162 & 0.00 & 0.875 & 0.288 & 0.199 \\
CSRSOC & 162 & 0.00 & 0.833 & 0.343 & 0.154 \\
CSRR & 162 & 0 & 1 & 0.03 & 0.173 \\
\hline
\end{tabular}

Tabel 4. Descriptive Statistic Model 2

\begin{tabular}{lcrrrr}
\hline Variable & $\mathbf{N}$ & Minimum & Maximum & Mean & Std. Deviation \\
\hline RET & 255 & -0.8834 & 1.9032 & 0.1065 & 0.444 \\
NI (in IDR) & 255 & $-2, \mathrm{E}+12$ & $7, \mathrm{E}+12$ & $6,11 \mathrm{E}+11$ & $1.449 \mathrm{E}+12$ \\
DNI (in IDR) & 255 & $-1, \mathrm{E}+12$ & $1, \mathrm{E}+12$ & $2,31 \mathrm{E}+10$ & $2.562 \mathrm{E}+11$ \\
DCSRENV & 255 & -0.1250 & 0.2500 & 0.0250 & 0.0988 \\
DCSRSOC & 255 & -0.1250 & 0.1667 & 0.0248 & 0.0633 \\
DCSRTOT & 255 & -0.1250 & 0.1875 & 0.0248 & 0.0549 \\
\hline
\end{tabular}


del, which is the extreme value between minimum and maximum and the standard deviation greater than the mean. This is one of the highlights from the descriptive statistics report and indicates that a concern for private companies where there is an imbalance between companies that have huge net income and less net income. Notes: By using the purposive sampling method, 60 data outliers with the result that the number of observations for the second model is 255 .

Table 5 showed the regression result. The results of the first hypothesis indicate that there is a positive influence between book value per share on shares prices. It can be interpreted that with the high book value per share, the value of the company will be high. The results of this study are the same as the research conducted by Verbeeten et al. (2016) found a positive influence between book value per share on shares prices, which means that if the book value per share is higher, it can encourage an increase in shares prices, and with increasing shares prices the value of the company will be better.

Table 5. Regression Results

\begin{tabular}{|c|c|c|c|}
\hline & Model 1 & $\begin{array}{c}\text { Model } 2 \\
\text { Enter } \\
\text { method }\end{array}$ & $\begin{array}{l}\text { Model } 2 \\
\text { Stepwise } \\
\text { method }\end{array}$ \\
\hline Constanta & $\begin{array}{c}0.010 \\
(84.961)\end{array}$ & $(0.076)$ & $(0.066)$ \\
\hline BVPS & $\begin{array}{c}0.000^{*} \\
(0.114)\end{array}$ & & \\
\hline NI & $\begin{array}{c}0.000^{*} \\
(0.000)\end{array}$ & $\begin{array}{c}0.618 \\
(0.000)\end{array}$ & \\
\hline CSRENV & $\begin{array}{c}0.192 \\
(105.119)\end{array}$ & & \\
\hline CSRSOC & $\begin{array}{r}0.006^{*} \\
(270.614)\end{array}$ & & \\
\hline CSRR & $\begin{array}{r}0.000^{*} \\
(1,456.563)\end{array}$ & & \\
\hline DNI & & $\begin{array}{c}0.006^{*} \\
(0.000)\end{array}$ & $\begin{array}{c}0.006^{*} \\
(0.000)\end{array}$ \\
\hline DCSRENV & & $\begin{array}{c}0.032^{*} \\
(-0.683)\end{array}$ & \\
\hline DCSRTOT & & $\begin{array}{c}0.001^{*} \\
(1.849)\end{array}$ & \\
\hline DCSRSOC & & & $\begin{array}{c}0.002^{*} \\
(1.367)\end{array}$ \\
\hline Adjusted R2 & 0.976 & 0.064 & 0.064 \\
\hline
\end{tabular}

Investors use book value per share in a company's valuation decision to complete the analysis of investors against balance sheet values (Vafaei et al., 2011). The same results were also found in several previous studies (Carnevale et al., 2012; Plumlee et al., 2015).

The results of the second hypothesis show a positive influence between net income on shares prices, which can be interpreted that high net income can increase the value of the company. Research result by Verbeeten et al. (2016) showing the same results, namely the positive influence of net income on shares prices. It can be interpreted that the higher the level of net income can increase shares prices, and with the increase in shares prices, the value of the company is getting better (Verbeeten et al., 2016).

From the results of the third hypothesis, it was found that there was no influence between environmental disclosure on shares prices. This can be interpreted that the level of environmental disclosure does not affect the value of the company. The results of this study are not by the research conducted by Clarkson et al. (2013) who found a positive influence between environmental disclosure on company value. However, the results of this study are in line with Verbeeten et al. (2016) who found no influence on environmental disclosures on shares prices. This is because investors cannot interpret environmental disclosure information and consider environmental disclosures irrelevant, so investors decide not to associate company value with environmental information. Also, the environmental information provided by the company cannot meet the needs of investors so investors are not interested in environmental disclosure information (Carnevale et al., 2012).

Based on the results of the fourth hypothesis, social disclosure has a positive influence on shares prices, so the higher the level of social disclosure can increase the value of the company. The results of this study are the same as the results of research conducted by Verbeeten et al. (2016) find a positive influence between social disclosure on shares prices, which means that an increase in social disclosure can increase com- 
pany value. Social disclosure gives an indication of the company's human resources, which can drive the company's financial performance in the future (Verbeeten et al., 2016). Then, social disclosure can be part of a risk management strategy that can reduce the risk of conflict (agency conflict) between the company and shareholders, because social disclosure by the company can reduce information mismatch between the company and shareholders associated with the company's social information (Verbeeten et al., 2016).

The results of the fifth hypothesis providing a separate CSR report from the annual report have a positive effect on shares prices. The results of the study are in accordance with the results of the study by Verbeeten et al. (2016) who found that a separate CSR report had a significant positive effect on shares prices, it can be interpreted that the provision of separate CSR reports can increase transparency of company information that can drive an increase in shares prices, the provision of separate CSR reports can increase shares prices, and with increasingly increasing shares prices, the value of the company will be better. A separate CSR report shows the company's efforts and commitment to increasing transparency regarding long-term performance (Dhaliwal et al., 2011). Separate CSR reports can provide more detailed and more comprehensive information that is useful for investors to evaluate the company's long-term sustainability (Dhaliwal et al., 2011), that investors can be more confident and believe that the investment they want to invest in the company will be safe and can provide benefits to investors. More investors investing in companies, the company's shares price will be increasing that indicated high value of the firm.

Sixth hypothesis result showed net income has a positive effect on return per share, which has been proven by previous research, which is done by (Verbeeten et al., 2016). On the other hand, there are contrasting results. Namely, net income does not affect the return per share (Cormier \& Magnan, 2007). The market conditions in each country are different, not ne- cessarily in Germany the same as in Indonesia, France or Canada, therefore it cannot be a linear formula that net income will increase return per share, especially markets in Indonesia which are very volatile about political conditions during the research period and prioritizing shareholders compared to stakeholders (Cormier \& Magnan, 2007; Verbeeten et al., 2016). The results of this study are in line with the research conducted by Cormier and Magnan (2007) where there is no influence between net income on return per share.

The results of the seventh hypothesis indicate that delta net income has a positive effect on return per share, meaning that every increase in delta net income will cause return per share to rise as well, indicating that the company has an increasingly good corporate value, the results of this study are in line with previous research (Verbeeten et al., 2016). As it is known that the backbone of a company is located at the level of sales or closely related to income, the higher the income the higher the profit generated, it should be underlined that delta is the profit difference this year with the previous year, it is crucial if there is a decrease in profits (Almeida et al., 2016).

The results of the eighth hypothesis show that the delta CSR social out of the model is due to the excluded variable, it uses a stepwise method, and it is proven that delta CSR social has a positive effect on return per share. This result is in line with previous research conducted by Verbeeten et al. (2016) which states that delta CSR social has a positive effect on return per share, the linear relationship between these two variables is very strong because the higher a company cares about CSR social will increase power attract investors for investment that causes a rise in corporate income along with the increase in corporate profits so that return per share will also increase (Arendt \& Brettel, 2010; Kuo et al., 2013). In Indonesia, CSR social activities are already very familiar to the public, especially business people, the public will look positively towards companies that care about their mea- 
Wahyuni Rusliyana Sari \& Anita Roosmalina Matusin/ Net Income and CSR Disclosure as Predictors Shares....

ning not only prioritizing profit but also caring for others to improve shared prosperity (Cheng \& Christiawan, 2011).

The results of the ninth hypothesis show that the delta CSR environment has a negative effect on return per share, meaning that the more companies care about the CSR environment, the lower the return per share, this result supports previous research conducted (Verbeeten et al., 2016). Nevertheless, the results of contrast are found in other studies as done by (Hassel et al., 2005). Back to the concept of disclosure of CSR environmental that the role of government in supporting this is very necessary because technological advances and the need for food are very dependent on employment, so there is no strict control from the regulator side, while professionals such as accountants are unable to do anything in quotes because big authority is in the company, it makes sense that the more companies CSR disclose environmental, the lower the return per share (Mishra \& Modi, 2013; Verbeeten et al., 2016).

The results of the tenth hypothesis show that total delta CSR is part of the CSR report where the use of scores will have a positive effect on return per share, the results of this study are in line with previous research as done by (Carnevale \& Mazzuca, 2014). The results of similar studies are reported to have a positive effect (Berthelot et al., 2012; Klerk et al., 2015; Plumlee et al., 2015; De Villiers \& Marques, 2016; Verbeeten et al., 2016).

In the first model the share price variable which can be explained by the book value per share, net income, CSR environment, CSR social, and CSR report is $97.6 \%$ while the $2.4 \%$ is explained by other factors not included in the research model. In contrast to the second model which has a small value of return per share variable which can be explained by the net income variable, delta net income, delta CSR environment, delta CSR social, and delta CSR total of $6.4 \%$ while the $93.6 \%$ is explained by other factors not included in the research model.

\section{CONCLUSION AND RECOMMENDATION}

Based on the results and discussions, it can be concluded as follows in the first model there is a positive influence between book value per share, net income, CSR social and CSR report on the share price. While the CSR environment does not affect share price, and in the second model, there is a positive influence between delta net income, delta CSR total, and delta CSR social on return per share. While the delta CSR environment has a negative effect on returns per share and net income does not affect return per share.

Recommendation for future researchers is add other variables such as return on equity (ROE) and earnings per shares (EPS) which are used as financial performance measurement variables (Carnevale et al., 2012) and using Robustness checks as a comparison with previous research, not only with a stepwise method (Verbeeten et al., 2016). According to no evidence of the influence of CSR environmental, this is clearly that measurements that rely on disclosure cannot capture the empirical results of CSR environmental in practices. This has been confirmed for a long time by the UN that measurement of CSR has two domains that are inseparable, namely liabilities and disclosure (United Nations, 1998).

\section{REFERENCES}

Al-Troudi, W., \& Milhem, M. (2013). Interdisciplinary Journal of Contemporary Research In Business Cash Dividends, Retained Earnings and Shares Prices: Evidence from Jordan. Interdisciplinary Journal of Contemporary Research in Business, 4(12), 585-599.

Almeida, H., Fos, V., \& Kronlund, M. (2016). The Real Effects of Share Repurchases. Journal of Financial Economics, 119(1), 168-185.

Almumani, M. A. (2014). Determinants of Equity Share Prices of the Listed Banks in Amman Shares Exchange: Quantitative Approach. International Journal of Business and Social Science, 5(1), 91-104.

Arendt, S., \& Brettel, M. (2010). Understanding the Influence of Corporate Social Responsibil- 
ity on Corporate Identity, Image, and Firm Performance. Management Decision, 48(10), 1469-1492.

Berthelot, S., Coulmont, M., \& Serret, V. (2012). Do Investors Value Sustainability Reports? a Canadian Study. Corporate Social Responsibility and Environmental Management, 19(6), 355363.

Bird, R., Hall, A. D., Momentè, F., \& Reggiani, F. (2007). What Corporate Social Responsibility Activities are Valued by the Market?. Journal of Business Ethics, 76(2), 189-206.

Carnevale, C., \& Mazzuca, M. (2014). Sustainability Report and Bank Valuation: Evidence from European Shares Markets. Business Ethics, 23(1), 69-90.

Carnevale, C., Mazzuca, M., \& Venturini, S. (2012). Corporate Social Reporting in European Banks: the Effects on a Firm's Market Value. Corporate Social Responsibility and Environmental Management, 19(3), 159-177.

Chakroun, R., Matoussi, H., \& Mbirki, S. (2016). Determinants of CSR Disclosure of Tunisian Listed Banks: a Multi Support Analysis. Social Responsibility Journal, 13(3), 552-584.

Cheng, B., Ioannou, I., \& Serafeim, G. (2014). Corporate Social Responsibility and Access to Finance. Strategic Management Journal, 35(1), 1-23.

Cheng, M., \& Christiawan, Y. J. (2011). Pengaruh Pengungkapan Corporate Social Responsibility terhadap Abnormal Return. Jurnal Akuntansi dan Keuangan, 13(1), 24-36.

Cho, C. H., Freedman, M., \& Patten, D. M. (2012). Corporate Disclosure of Environmental Capital Expenditures: a Test of Alternative Theories. Accounting, Auditing and Accountability Journal, 25(3), 486-507.

Clarkson, P. M., Fang, X., Li, Y., \& Richardson, G. (2013). The Relevance of Environmental Disclosures: are Such Disclosures Incrementally Informative?. Journal of Accounting and Public Policy, 32(5), 410-431.

Cormier, D., \& Magnan, M. (2007). The Revisited Contribution of Environmental Reporting to Investors' Valuation of a Firm's Earnings: an International Perspective. Ecological Economics, 62(3), 613-626.

Da Silva Monteiro, S. M., \& Aibar-Guzmán, B. (2010). Determinants of environmental disclosure in the annual reports of large compa- nies operating in Portugal. Corporate Social Responsibility and Environmental Management, 17(4), 185-204.

De Klerk, M., de Villiers, C., \& van Staden, C. (2015). The influence of corporate social responsibility disclosure on share prices: Evidence from the United Kingdom. Pacific Accounting Review, 27(2), 208-228.

De Villiers, C., \& Marques, A. (2016). Corporate Social Responsibility, Country-Level Predispositions, and the Consequences of Choosing a Level of Disclosure. Accounting and Business Research, 46(2), 167-195.

Dhaliwal, D., Li, O. Z., Tsang, A., \& Yang, Y. G. (2014). Corporate Social Responsibility Disclosure and the Cost of Equity Capital: the Roles of Stakeholder Orientation and Financial Transparency. Journal of Accounting and Public Policy, 33(4), 328-355.

Dhaliwal, D. S., Li, O. Z., Tsang, A., \& Yang, Y. G. (2011). Voluntary Nonfinancial Disclosure and the Cost of Equity Capital: the Initiation of Corporate Social Responsibility Reporting. Accounting Review, 86(1), 59-100.

Dhaliwal, D. S., Radhakrishnan, S., Tsang, A., \& Yang, Y. G. (2012). Nonfinancial Disclosure and Analyst Forecast Accuracy: International Evidence on Corporate Social Responsibility Disclosure. The Accounting Review, 87(3), 723-759.

Flammer, C. (2015). Does Corporate Social Responsibility Lead to Superior Financial Performance? a Regression Discontinuity Approach. Management Science, 61(11), 2549-2568.

Gamerschlag, R., Möller, K., \& Verbeeten, F. (2011). Determinants of Voluntary CSR Disclosure: Empirical Evidence from Germany. Review of Managerial Science, 5(2-3), 233-262.

Garcia-Sanchez, I. M., Cuadrado-Ballesteros, B., \& Sepulveda, C. (2014). Does Media Pressure Moderate CSR Disclosures by External Directors ?. Management Decision, 52(6), 1014-1045.

Gitman, L. J., \& Zutter, C. J. (2015). Principles of Managerial Finance, 14th edition. USA: Pearson.

Hassel, L., Nilsson, H., \& Nyquist, S. (2005). The Value Relevance of Environmental Performance. European Accounting Review, 14(1), 41-61.

Kim, Y., Park, M. S., \& Wier, B. (2012). Is Earnings Quality Associated with Corporate Social 
Wahyuni Rusliyana Sari \& Anita Roosmalina Matusin/ Net Income and CSR Disclosure as Predictors Shares....

Responsibility?. The Accounting Review, 87(3), 761-796.

Kuo, L., Chen, V. Y., \& Chen, V. Y. (2013). Is Environmental Disclosure an Effective Strategy on Establishment of Environmental Legitimacy for Organization?. Management Decision, 51(7), 1462-1487.

Lys, T., Naughton, J. P., \& Wang, C. (2015). Signaling through Corporate Accountability Reporting. Journal of Accounting and Economics, 60(1), 56-72.

Malhotra, N., \& Tandon, K. (2013). Determinants of Shares Prices: Empirical Evidence from NSE 100 Companies. International Journal of Research in Management \& Technology, 3(3), 2249-9563.

Malik, M. (2015). Value-Enhancing Capabilities of CSR: a Brief Review of Contemporary Literature. Journal of Business Ethics, 127(2), 419-438.

Mishra, S., \& Modi, S. B. (2013). Positive and Negative Corporate Social Responsibility, Financial Leverage, and Idiosyncratic Risk. Journal of Business Ethics, 117(2), 431-448.

Plumlee, M., Brown, D., Hayes, R. M., \& Marshall, R. S. (2015). Voluntary Environmental Disclosure Quality and Firm Value: Further Evidence. Journal of Accounting and Public Policy, 34(4), 336-361.

Reverte, C. (2009). Determinants of Corporate Social Responsibility Disclosure Ratings by Spanish Listed Firms. Journal of business ethics, 88(2), 351-366.

Reverte, C. (2012). The Impact of Better Corporate Social Responsibility Disclosure on the Cost of Equity Capital. Corporate Social Responsibility and Environmental Management, 19(5), 253-272.

Reverte, C. (2016). Corporate Social Responsibility Disclosure and Market Valuation: Evidence from Spanish Listed Firms. Review of Managerial Science, 10(2), 411-435.

Sekaran, U., \& Bougie, R. (2013). Research Method for Business. A Skill-Building Approach. 6th edition. New Jersey: John Wiley \& Sons, Ltd.

Sharma, S. (2011). Determinants of Equity Share Prices in India. Journal of Arts, Science \& Commerce, 2(4), 51-60.

Srinivasan, P. (2012). Determinants of Equity Share Prices in India: a Panel Data Approach. The Romanian Economic Journal, 15(46), 205228.

United Nations. (1998). Accounting and Financial Reporting for Environmental Costs and Liabilities. United Nations Conference on Trade and Development Geneva UNCTAD/ITE/ EDS/4.

Vafaei, A., Taylor, D., \& Ahmed, K. (2011). The Value Relevance of Intellectual Capital Disclosures. Journal of Intellectual Capital, 12(3), 407-429.

Verbeeten, F. H. M., Gamerschlag, R., \& Möller, K. (2016). Are CSR Disclosures Relevant for Investors? Empirical Evidence from Germany. Management Decision, 54 Issue:(6), 13591382.

Xu, X. D., Zeng, S. X., \& Tam, C. M. (2012). Shares Market's Reaction to Disclosure of Environmental Violations: Evidence from China. Journal of Business Ethics, 107(2), 227-237. 